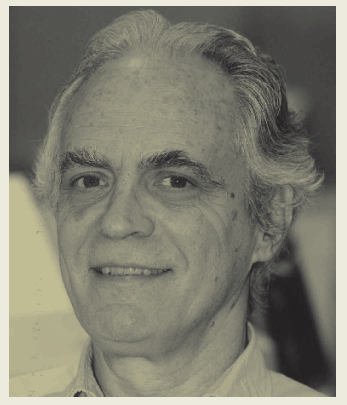

\title{
2018: UMA DIFÍCIL TRAVESSIA
}

São necessários, no mínimo, três pés para sustentar uma mesa. Um governo, no entanto, pode cambalear sem cair apoiando-se apenas em dois. No caso brasileiro, o suporte vem do Congresso e dos donos do produto interno bruto (PIB). Para utilizar o jargão do futebol: o presidente Michel Temer é um Pelé (ou melhor Maradona, lembram-se da mão de Deus?) em suas relações com deputados e senadores, um Neném Prancha (quem pede recebe...) quando conversa com os grandes empresários - especialmente os inadimplentes, que adoram um perdão tributário, mais conhecido por Programa de Recuperação Fiscal (Refis) - e um cabeça de bagre (sapo) quando tenta se comunicar com o povão nas ruas. Tudo indica que chegará ao fim de seu mandato, se outra dupla sertaneja não tentar tostá-lo em novo churrasco.

Para um político que vive de votos, Temer toma decisões surpreendentes. Coloca todas as fichas em medidas impopulares (embora necessárias), como a reforma previdenciária, e concede um reajuste de mesquinhez inigualável ao salário-mínimo. Sua esperança: que a economia continue melhorando, com inflação baixa, emprego em alta, crescimento do PIB e aumento da renda.

Esses fatores têm contribuído para uma pequena elipse virtuosa: o PIB saiu do vermelho em 2017 e o desemprego começou a ceder. Embora pequenos, esses avanços contribuem para o crescimento das receitas tributárias e previdenciárias. A queda da taxa Selic reduz as despesas da rolagem da dívida pública e, ao mesmo tempo, reanima os crediários e o consumo.
O raquítico reajuste do salário-mínimo também dá uma pequena contribuição para a redução das despesas previdenciárias. Se em fevereiro a reforma da previdência, mesmo desidratada, ou melhor, liofilizada, for votada e contribuir para diminuir o rombo da seguridade social, é possível que o deficit primário (despesas, sem contar juros, maiores que receitas) seja reduzido ou mesmo se aproxime do equilíbrio.

Nesse caso, surgirá um sinal importante na linha do horizonte: se a taxa de crescimento da dívida pública for igual ou inferior à do PIB, as luzes da sustentabilidade vão se acender e os investimentos voltarão de forma decidida. A dinâmica da economia deixará de ser sustentada pelo consumo (como acontece hoje) e passará a se apoiar no investimento, forma sustentável de garanti-lo no médio e no longo prazo.

Ocorre que o apoio de parlamentares e empresários exige favores e concessões, que remam contra o ajuste fiscal. Liberação de emendas, desoneração da folha de pagamento, anistias fiscais e outras gracinhas comprometem o equilíbrio das contas do governo no momento em que estados, sem dinheiro para pagar funcionários, declaram calamidade pública e vendem a alma para o primeiro comprador.

O recente rebaixamento na classificação do Brasil por uma das agências de rating acendeu a luz amarela. Se o governo conseguir algum avanço na votação da reforma da previdência é possível que, em 2018, presenciemos uma situação de "empate técnico" em relação ao equilíbrio fiscal: receitas crescentes pela expansão do PIB, sem que as despesas apresentem sinal de queda. O resto fica por conta das incertezas da eleição presidencial. 